\title{
APPLICATION OF ROM SCALE FOR ESTIMATING BANK EROSION VULNERABLE AREAS IN KAMRUP DISTRICT, ASSAM
}

\author{
Dr. Indira Das \\ Research Scholar, Department of Geography, \\ Gauhati University, Assam, India \\ Sujit Deka \\ Professor and HoD., \\ Department of Geography, Bodoland University, Assam, India
}

\begin{abstract}
The paper presents an overview of bank erosion which is a very devastating and recurring hazard in southern part of Kamrup District. For application of anti-erosive measures, it is necessary to spot the locations vulnerable to bank erosion. Many methodologies are available to predict the strength and weaknesses of river bank against erosion. The El ROM equation is one such established methodology to assess the extent of erosion on the basis of soil composition. In this work the validity of this methodology is checked in the southern tributaries of the river Brahmaputra namely, Kulsi, Boko, Singra and Singhua. It was observed that the erodibility factor of the soil of the various sample locations have high composition of sand and silt which are highly susceptible to erosion. After analyzing the result, it has come to light that this method gives very much acceptable results in identifying the highly erosion prone areas. Since our main concern is the proper identification of erosion hazard locations, it can be finally concluded that this El ROM equation can be effectively and widely used to identify the risky and erosion vulnerable locations for proper implementation of anti-erosion measures.
\end{abstract}

Key words: Bank erosion, hazards, $\mathrm{El}_{\mathrm{ROM}}$ equation, soil composition, vulnerable

Cite this Article: Indira Das and Sujit Deka, Application of Rom Scale for Estimating Bank Erosion Vulnerable Areas in Kamrup District, Assam, International Journal of Management, 11(12), 2020, pp 1652-1656.

http://iaeme.com/Home/issue/IJM?Volume=11\&Issue=12 


\section{INTRODUCTION}

Bank erosion is a natural geomorphic process or disruption that ensues in the course of a river or subsequently after floods (Florsheim et al, 2008). River bank erosion occurs due to mechanical weathering of the bank materials (Duan, 2005; Thorne, 1991). This results from a composite set of relation between hydraulic action of the river and characteristics of the bank materials. Basically, bank erosion embraces two correlated processes that is mass wasting and fluvial erosion (Hooke 1979, Odgaard 1987, Osman and Thorne 1988, Hasegawa 1989, Lawler 1993, Darby and Thorne 1996, Casagli et al. 1999). Bank erosion and aggradation is a rising concern in the southern part of Kamrup district in Assam. Every year valuable agricultural land is affected by erosion and deposition by the river Brahmaputra, Kulsi, Singra, Singhua and Boko. A vast track of land especially in Goroimari, Palasbari, Chamaria and Nagarbera revenue circles are affected by flood and bank erosion. Breaching of embankments owing to high flood is also common in the area. From 2014 to 2016, an area of 882.7 hectares was eroded while during 1991 to 2004, an area of 2125.2 hectares of land had been eroded (Das, 2020). The anti-erosion scheme in the study area is being taken up by the Flood and River Erosion Management and Asian Development Bank. This project includes an all-inclusive riverbank protection in the Palasbari and Gumi area. The tributaries of the river Brahmaputra namely, Kulsi, Singra, Singhua and Boko also possess highly meandering courses that are susceptible to bank erosion and migration.

\section{LOCATION OF STUDY AREA}

This study concentrates in the Lower Brahmaputra floodplain drained by the Kulsi, Boko, Singra and Singhua- four dynamic south-bank tributaries of the river Brahmaputra, Assam (Figure 1). These rivers originate in the Meghalaya Plateau and carry heavy sediment loads, and enter the plains through narrow outlets with a great velocity. The area is tectonically active (Lahiri and Sinha, 2012). The catchments, both in the plateau and plain, experience heavy rainfall during the monsoon season resulting in excess surface runoff inundating huge area in the plains used primarily for agricultural purposes.

\section{OBJECTIVES}

The main objective of the study is to locate the vulnerable bank erosion locations.

\section{METHODOLOGY}

The banklines of each of the rivers were delineated from 1970 to 2016 in ArcGIS 10.5 software. These banklines were superimposed together to identify the eroded areas. A pilot survey was also done as a basis for ground accuracy. Based on the identified areas a total of 33 samples were collected from the bank and beds of the four rivers at eleven locations. The laboratory analysis specifically sieves and hydrometer evaluation was performed to investigate the proportion of soil texture composition. Soil erodibility is the vulnerability of soil to erosional processes (Bryan et al, 1989). Soil texture and structure are the most important determinants of soil erodibility (Bouyoucos, 1962). It is an important index to determine soil sensitivity towards erosion (Zhang et al, 2004). The erodibility factor for a soil can be affected by the composition of sand, silt and clay. High composition of sand and silt means that the soil can easily be eroded since they are fine in size and can be easily carried away by surface run off (Roslan et al., 2012). Efforts have been made to obtain an index of erodibility and in this context the Bouyoucos Erodibility Index forwarded by a scientist named Bouyoucos in 1962 has been widely appreciated. The equation followed that erodibility is proportional to the following ratio: 
Bouyoucos Erodibility Index = (\% of Sand +\% of Silt $) /(\%$ of Clay)

The Bouyoucos erodibility index has led to the development of the EI ROM equation or ROM scale named after the researchers Roslan and Mazidah (Table 1). This equation analyses the composition of sand, silt and clay in soil. This is the first ever scale created to grade the degree of erosions with regards to soil erodibility in Malaysia. The river bank classification index with regards to the percentage of sand, silt and clay are given below

$$
E I_{R O M}=\% \text { Sand }+\% \text { Silt } / 2(\% \text { Clay })
$$

Table 1: 'ROM' Scale with regard to soil erodibility category

\begin{tabular}{|c|c|}
\hline 'Rom' scale & Soil erodibility category \\
\hline$<1.5$ & Low \\
\hline $1.5-4.0$ & Moderate \\
\hline $4.0-8.0$ & High \\
\hline $8.0-12.0$ & Very High \\
\hline$>12.0$ & Critical \\
\hline
\end{tabular}

Source: Roslan and Mazidah, 2012

\section{RESULTS AND DISCUSSIONS}

To have an in-depth knowledge of the areas susceptible to bank erosion, a number of soil samples are collected from the banks of the rivers of the study area and examined using analytical procedure and testing it in the laboratory. The soil texture composition found has been tabulated in table 2

Table 2 Soil Texture of bed and bank materials of river Boko, Kulsi, Singra and Singhua

\begin{tabular}{|c|c|c|c|c|c|}
\hline \multirow[t]{3}{*}{ River } & \multicolumn{5}{|c|}{ Soil textural composition } \\
\hline & \multicolumn{2}{|r|}{ Sample } & \multicolumn{2}{|c|}{ Bank materials } & \multirow[t]{2}{*}{ Bed materials } \\
\hline & No. & Location & Left & Right & \\
\hline \multirow[t]{6}{*}{ Boko } & \multirow[t]{2}{*}{ S1 } & \multirow[t]{2}{*}{ Makali } & Sandy loam & Loam & Sand \\
\hline & & & $\begin{array}{l}\text { Sand-74\%, silt- } \\
17 \% \text {, clay-9\% }\end{array}$ & $\begin{array}{l}\text { Sand- } 45 \% \text {, silt- } \\
29 \% \text {, clay-26\% }\end{array}$ & $\begin{array}{l}\text { Sand- } 90 \% \text {, silt- } \\
1 \% \text {, clay- } 9 \%\end{array}$ \\
\hline & \multirow[t]{2}{*}{$\mathrm{S} 2$} & \multirow[t]{2}{*}{ Barpara } & Loamy sand & Loamy & Sand \\
\hline & & & $\begin{array}{l}\text { Sand- } 80 \% \text {, silt- } \\
15 \% \text {, clay-5\% }\end{array}$ & $\begin{array}{l}\text { Sand- } 50 \% \text {, silt- } \\
32 \% \text {, clay- } 18 \%\end{array}$ & $\begin{array}{l}\text { Sand- } 90 \% \text {, silt- } \\
1 \% \text {, clay- } 9 \%\end{array}$ \\
\hline & \multirow[t]{2}{*}{ S3 } & \multirow[t]{2}{*}{ Lepgaon } & Loamy sand & Sandy loam & Sand \\
\hline & & & $\begin{array}{l}\text { Sand- } 81 \% \text {, silt- } \\
12 \% \text {, clay-7\% }\end{array}$ & $\begin{array}{l}\text { Sand- } 73 \% \text {, silt- } \\
22 \% \text {, clay-5\% }\end{array}$ & $\begin{array}{l}\text { Sand-91\%, silt- } \\
1 \% \text {, clay- } 8 \%\end{array}$ \\
\hline \multirow{8}{*}{ Kulsi } & \multirow[t]{2}{*}{ S4 } & \multirow[t]{2}{*}{ Mandira Pathar } & Loamy sand & Sandy loam & Sand \\
\hline & & & $\begin{array}{l}\text { Sand-79\%, silt- } \\
18 \% \text {, clay-3\% }\end{array}$ & $\begin{array}{l}\text { Sand- } 72 \% \text {, silt- } \\
24 \% \text {, clay- } 4 \%\end{array}$ & $\begin{array}{l}\text { Sand- } 90 \% \text {, silt- } \\
2 \% \text {, clay- } 8 \%\end{array}$ \\
\hline & \multirow[t]{2}{*}{ S5 } & \multirow[t]{2}{*}{ Aggumi } & Sandy loam & Sandy loam & Sand \\
\hline & & & $\begin{array}{l}\text { Sand- } 68 \% \text {, silt- } \\
28 \% \text {, clay- } 4 \%\end{array}$ & $\begin{array}{l}\text { Sand- } 66 \% \text {, silt- } \\
26 \% \text {, clay-8\% }\end{array}$ & $\begin{array}{l}\text { Sand-91\%, silt- } \\
1 \% \text {, clay- } 8 \%\end{array}$ \\
\hline & \multirow[t]{2}{*}{ S6 } & \multirow[t]{2}{*}{ Dakuapara } & Sandy loam & Sandy loam & Sand \\
\hline & & & $\begin{array}{l}\text { Sand-78\%, silt- } \\
13 \% \text {, clay-9\% }\end{array}$ & $\begin{array}{l}\text { Sand- } 66 \% \text {, silt- } \\
26 \% \text {, clay- } 8 \%\end{array}$ & $\begin{array}{l}\text { Sand- } 90 \% \text {, silt- } \\
2 \% \text {, clay- } 8 \%\end{array}$ \\
\hline & \multirow[t]{2}{*}{ S7 } & \multirow[t]{2}{*}{ Ukiam } & Sandy loam & Sandy loam & Sand \\
\hline & & & $\begin{array}{l}\text { Sand-74\%, silt- } \\
19 \% \text {, clay-7\% }\end{array}$ & $\begin{array}{l}\text { Sand- } 66 \% \text {, silt- } \\
26 \% \text {, clay- } 8 \%\end{array}$ & $\begin{array}{l}\text { Sand- } 90 \% \text {, silt- } \\
2 \% \text {, clay- } 8 \%\end{array}$ \\
\hline \multirow[t]{4}{*}{ Singra } & \multirow[t]{2}{*}{ S8 } & \multirow[t]{2}{*}{ Dhopguri } & Loamy sand & Loamy sand & Sand \\
\hline & & & $\begin{array}{l}\text { Sand- } 80 \% \text {, silt- } \\
15 \% \text {, clay-5\% }\end{array}$ & $\begin{array}{l}\text { Sand- } 82 \% \text {, silt } \\
12 \% \text {, clay- } 6 \%\end{array}$ & $\begin{array}{l}\text { Sand- } 90 \% \text {, silt- } \\
0 \% \text {, clay- } 10 \%\end{array}$ \\
\hline & \multirow[t]{2}{*}{ S9 } & \multirow[t]{2}{*}{ Hahim } & Loamy sand & Loamy sand & Sand \\
\hline & & & Sand- $83 \%$, silt- & Sand- $84 \%$, silt- & Sand-91\%, silt- \\
\hline
\end{tabular}




\begin{tabular}{|c|c|c|c|c|c|}
\hline & & & $5 \%$, clay- $12 \%$ & $3 \%$, clay- $13 \%$ & $0 \%$, clay- $9 \%$ \\
\hline & \multirow[t]{2}{*}{ S10 } & \multirow[t]{2}{*}{ Rajapara } & Loamy sand & Loamy sand & Sand \\
\hline & & & $\begin{array}{l}\text { Sand-79\%, silt- } \\
5 \% \text {, clay- } 6 \%\end{array}$ & $\begin{array}{l}\text { Sand- } 80 \% \text {, silt- } \\
13 \% \text {, clay-7\% }\end{array}$ & $\begin{array}{l}\text { Sand- } 91 \% \text {, silt- } \\
1 \% \text {, clay- } 8 \%\end{array}$ \\
\hline \multirow[t]{2}{*}{ Singhua } & \multirow[t]{2}{*}{ S11 } & \multirow[t]{2}{*}{ Kalipara } & Loamy sand & Loamy sand & Sand \\
\hline & & & $\begin{array}{l}\text { Sand- } 83 \% \text {, silt- } \\
5 \% \text {, clay- } 12 \%\end{array}$ & $\begin{array}{l}\text { Sand- } 84 \% \text {, silt- } \\
3 \% \text {, clay- } 13 \%\end{array}$ & $\begin{array}{l}\text { Sand- } 82 \% \text {, silt- } \\
7 \% \text {, clay- } 11 \%\end{array}$ \\
\hline
\end{tabular}

Source: Soil samples collected by the researchers and tested in laboratory

Based on the soil texture results found in the laboratory test, the degree of soil erodibility has been derived for the river samples, affected, and their percentage composition of sand, clay and silt are enumerated to know the cohesivity of soils. Ascertaining the soil erodibility level as critical, very high, high, moderate and low, bank erosion risk at several sample sites, along the river bank can easily be identified (Table 3 ).

Table 3 Soil erodibility of soil samples

\begin{tabular}{|l|l|c|l|c|l|c|l|}
\hline \multirow{2}{*}{ Sample Location } & \multicolumn{2}{|c|}{ Left Bank } & \multicolumn{2}{c|}{ Bed Material } & \multicolumn{2}{c|}{ Right Bank } \\
\cline { 3 - 8 } \multicolumn{2}{|c|}{} & $\begin{array}{c}\text { Rom } \\
\text { Scale }\end{array}$ & $\begin{array}{c}\text { Soil } \\
\text { erodibility } \\
\text { category }\end{array}$ & $\begin{array}{c}\text { Rom } \\
\text { Scale }\end{array}$ & $\begin{array}{c}\text { Soil } \\
\text { erodibility } \\
\text { category }\end{array}$ & Rom Scale & $\begin{array}{c}\text { Soil } \\
\text { erodibility } \\
\text { category }\end{array}$ \\
\hline \multirow{3}{*}{$\begin{array}{l}\text { Boko } \\
\text { River }\end{array}$} & Makali & 5.1 & High & 10.1 & Very High & 2.8 & Low \\
\cline { 2 - 8 } & Barpara & 9.5 & Very High & 10.1 & Very High & 4.5 & High \\
\cline { 2 - 8 } $\begin{array}{l}\text { Kulsi } \\
\text { River }\end{array}$ & Lepgaon & 6.6 & High & 11.5 & Very High & 9.5 & Very High \\
\cline { 2 - 8 } & Pathar & 16 & Critical & 10.1 & Very High & 12 & Critical \\
\cline { 2 - 8 } & Aggumi & 12 & Critical & 11.5 & Very High & 9.5 & Very High \\
\cline { 2 - 9 } & Dakuapara & 5.01 & High & 11.5 & Very High & 5.8 & High \\
\hline \multirow{2}{*}{$\begin{array}{l}\text { Singra } \\
\text { River }\end{array}$} & Dkiam & 6.6 & High & 10.1 & Very High & 5.8 & High \\
\cline { 2 - 9 } & Dhopguri & 9.5 & Very High & 9 & Very High & 7.8 & Very High \\
\hline \multirow{2}{*}{$\begin{array}{l}\text { Singhua } \\
\text { River }\end{array}$} & Rajapara & 15 & Critical & 11.5 & Very High & 13 & Critical \\
\cline { 2 - 9 } & Kalipara & 3.6 & Moderate & 10.11 & Very High & 3.3 & Moderate \\
\hline
\end{tabular}

It is observed in river Boko that other than the right bank materials at Makali, all the other sample locations are susceptible to erosion according to the 'ROM' Scale. Similarly, the sample location points Mandira Pathar and Agumi in river Kulsi is at critical risk of erosion. Both the sample locations of river Singra i.e., Dhopguri and Hahim represents very high risk of erosion. The sample location of Dhopguri in river Singra represents very high risk of erosion while Hahim is at moderate risk. It is noticed that both the banks of Rajapara in is at critical risk of erosion while Kalipara is at moderate risk of erosion. However, it can be seen that bed materials of all the sites are at very high risk of erosion. Thus, it is understood that the erodibility factor of the soil of the sample locations at the different rivers of the study area have high composition of sand and silt which are easily eroded away by flood water.

\section{CONCLUSION}

Most of the soil categories in the study area have soils that have a higher proportion of sand and thus have greater risk of bank collapse. Sandy soil is recognized for its minimal cohesive force and thus more susceptible to erosion and transportation by stream. Moreover, sandy soil supports greater proportion of water absorptivity into the soil. This is validated and established by the "Rom" Scale calculation where maximum number of the soil samples were sorted as very high and critical in the degree level of erosion vulnerability and is susceptible 
to bank failure. With this noteworthy statistics, suitable mitigating methods can be planned for prevention of bank erosion.

\section{REFERENCES}

[1] Bouyoucos, G. J. Improved hydrometer method for making particle size analysis. Agronomy. Journal, 54, 1962, pp. 464-465.

[2] Bryan, R. B., Govers, G., \& Poesen, J. The concept of soil erodibility and some problems of assessment and application. Catena, 16(4-5), 1989, pp. 393-412.

[3] Casagli, N., Rinaldi, M., Gargini, A., \& Curini, A. Pore water pressure and streambank stability: results from a monitoring site on the Sieve River, Italy. Earth Surface Processes and Landforms: The Journal of the British Geomorphological Research Group, 24(12), 1999, pp. 1095-1114.

[4] Darby, S. E., \& Thorne, C. R. Development and testing of riverbank-stability analysis. Journal of hydraulic engineering, 122(8), 1996, pp. 443-454.

[5] Das, I, Geomorphic Hazards and management in the Southern part of Kamrup District, Assam, Ph.D. Dissertation, Gauhati University, 2000.

[6] Duan, J. G. Analytical approach to calculate rate of bank erosion. Journal of hydraulic engineering, 131(11), 2005, pp. 980-990.

[7] Florsheim, J. L., Mount, J. F., \& Chin, A. Bank erosion as a desirable attribute of rivers. Bio Science, 58(6), 2008, pp. 519-529.

[8] Hasegawa, K. Universal bank erosion coefficient for meandering rivers. Journal of Hydraulic Engineering, 115(6), 1989, pp. 744-765.

[9] Hooke, J. M. An analysis of the processes of river bank erosion. Journal of hydrology, 42(12), 1979, pp. 39-62.

[10] Lahiri, S.K., \& Sinha, R. Tectonic controls on the morphodynamics of the Brahmaputra River system in the upper Assam valley, India. Geomorphology, 169-170, 2012, pp. 74-85.

[11] Lawler, D. M. The measurement of river bank erosion and lateral channel change: a review. Earth surface processes and landforms, 18(9), 1993, pp. 777-821.

[12] Odgaard, A. J. Streambank erosion along two rivers in Iowa. Water Resources Research, 23(7), 1987, pp. 1225-1236.

[13] Osman, A. M., \& Thorne, C. R. Riverbank stability analysis. I: Theory. Journal of Hydraulic Engineering, 114(2), 1988, 134-150.

[14] Roslan, Z. A., Naimah, Y., \& Roseli, Z. A. River bank erosion risk potential with regards to soil erodibility. In: Brebbia, C.A., ed., River Basin Management VII: Wessex Institute of Technology, UK, 2012, pp. 289.

[15] Thorne, C. R. Bank erosion and meander migration of the Red and Mississippi Rivers, USA. IAHS PUBL, IAHS, WALLINGFORD, (ENGL), (201), 1991, pp. 301-313.

[16] Zhang, K., Li, S., Peng, W., \& Yu, B. Erodibility of agricultural soils on the Loess Plateau of China. Soil and Tillage Research, 76(2), 2004, pp. 157-165. 